\title{
Immunological status of peripheral blood is associated with prognosis in patients with bone and soft-tissue sarcoma
}

\author{
YOUNGJI KIM $^{1-3}$, EISUKE KOBAYASHI ${ }^{1}$, YOSHIYUKI SUEHARA ${ }^{2}$, AYUMU ITO ${ }^{4}$, DAISUKE KUBOTA ${ }^{1,2}$, \\ YOSHIKAZU TANZAWA ${ }^{1}$, MAKOTO ENDO ${ }^{1}$, FUMIHIKO NAKATANI ${ }^{1}$, TETSUYA NAKATSURA ${ }^{3}$, \\ AKIRA KAWAI $^{1}$, KAZUO KANEKO ${ }^{2}$ and SHIGEHISA KITANO ${ }^{3,5,6}$ \\ ${ }^{1}$ Division of Musculoskeletal Oncology, National Cancer Center Hospital, Tokyo 104-0045; \\ ${ }^{2}$ Department of Orthopedic Surgery, Juntendo University School of Medicine, Tokyo 113-8431; \\ ${ }^{3}$ Division of Cancer Immunotherapy, Exploratory Oncology Research and Clinical Trial Center, \\ National Cancer Center Hospital, Tokyo 104-0045; Departments of ${ }^{4}$ Hematopoietic Stem Cell Transplantation, and \\ ${ }^{5}$ Experimental Therapeutics, National Cancer Center Hospital, Tokyo 104-0045; \\ ${ }^{6}$ Division of Cancer Immunotherapy Development, Advanced Medical Development Center, \\ The Cancer Institute Hospital of Japanese Foundation for Cancer Research, Tokyo 135-8550, Japan
}

Received June 27, 2020; Accepted October 23, 2020

DOI: $10.3892 / \mathrm{ol} .2021 .12473$

\begin{abstract}
Immune-checkpoint inhibitors have shown promising antitumor effects against certain types of cancer. However, specific immune-checkpoint inhibitors for patients with sarcoma have yet to be identified, whereas the immunological status of peripheral blood in patients with bone sarcoma and soft-tissue sarcoma (STS) remains unknown. In addition, it is unclear whether the immunological status from the peripheral blood could be used as a prognostic indicator. Therefore, the present study aimed to clarify the immunological status of peripheral blood samples derived from patients with bone sarcoma and STS. Immune monitoring was performed using the peripheral blood samples of 61 patients with no metastasis of high-grade sarcoma. A total of 25 patients with metastatic sarcoma were used for comparison. A total of 41 immune cell subsets were analyzed using multicolor-flow cytometry. The patients that did not have metastasis demonstrated higher quantities of monocytic myeloid-derived suppressor cells (M-MDSCs) and T cell immunoglobulin and mucin domain- $3(\mathrm{Tim}-3)^{+} \mathrm{CD}^{+} \mathrm{T}$ cells, which were significantly associated with poor disease-free survival (DFS) time, while higher quantities of $\mathrm{NKG}_{2} \mathrm{D}^{+} \mathrm{CD} 8^{+}$ $\mathrm{T}$ cells were significantly associated with improved DFS time.
\end{abstract}

Correspondence to: Dr Shigehisa Kitano, Division of Cancer Immunotherapy Development, Advanced Medical Development Center, The Cancer Institute Hospital of Japanese Foundation for Cancer Research, 3-8-31 Ariake, Koto-ku, Tokyo 135-8550, Japan E-mail: shigehisa.kitano@jfcr.or.jp

Key words: immunological status, bone and soft-tissue sarcoma, myeloid-derived suppressor cells, natural killer group 2 member D, T cell immunoglobulin and mucin domain 3
Multivariate Cox regression analysis demonstrated that the number of $\mathrm{Tim}-3^{+} \mathrm{CD} 8^{+} \mathrm{T}$ cells was associated with lower DFS time. A significant association was also found between the number of M-MDSCs and progression-free survival (PFS) time in patients with metastasis. The results suggested the occurrence of immune surveillance, which indicated that the host immune reaction against cancer existed in patients with bone sarcoma and STS. Notably, a high number of M-MDSCs was associated with both DFS and PFS time, suggesting a strong prognostic value. The data suggested that the immune status of peripheral blood was associated with the prognosis in patients with sarcoma, as previously reported in patients with other cancer types. In summary, the results may assist with the development of novel strategies for sarcoma treatment, based on the use of biomarkers or immunotherapy.

\section{Introduction}

Bone sarcomas and soft-tissue sarcomas (STSs) are very rare and biologically heterogeneous malignancies. There are 0.8 malignant bone tumors and $\sim 2$ malignant soft tissue sarcomas per 100,000 . These are very few compared with that in other types of cancer in 2013. In addition, malignant bone tumors and soft tissue sarcomas are classified into $\sim 20$ and 40 types, respectively (1). The treatment option for patients with advanced STS is single systemic chemotherapy (2). In contrast to bone sarcomas and STSs, osteosarcoma (OS) and the Ewing sarcoma family of tumors (ESFT) are the most frequent primary malignant bone tumors found in adolescents and young adults, worldwide $(3,4)$. The introduction of preoperative chemotherapy has significantly improved the overall survival time of these patients $(5,6)$. Nevertheless, the prognosis of patients with OS and ESFT, who exhibit a poor response to chemotherapy remains unfavorable, due to their high risk of developing distant metastases. The mainstay of treatment for other bone sarcoma tumors, such as chondrosarcoma and 
chordoma is surgical resection. The use of chemotherapy for these bone tumors is considered ineffective $(7,8)$.

Immune surveillance against tumors has attracted considerable attention, due to the development of immune-checkpoint inhibitors, that have shown antitumor effects against certain types of cancer, such as breast, colorectal, gastric, lung, pancreatic and renal cancers $(9,10)$. The balance between activation and inhibition of immune responses may determine whether cancers can avoid detection based on immune recognition. The simultaneous inhibition of more than one immune target may regulate the expression level of various molecules, including programmed death-1 (PD-1), cytotoxic T lymphocyte-associated molecule-4 (CTLA-4), lymphocyte-activation gene-3 (LAG-3), T cell immunoglobulin and mucin domain-3 (Tim-3) and natural killer group 2 member A (NKG2A), which have also been recognized as immune-checkpoint molecules that are present on the surface of $\mathrm{CD}^{+}$and $\mathrm{CD}^{+} \mathrm{T}$ cells (11-14). Furthermore, co-stimulated activated molecules, such as CD28, CD134 (OX-40), CD137 (4-1BB), inducible co-stimulatory molecule (ICOS) and natural killer group 2 member D (NKG2D), are also known to be present on the surface of $\mathrm{CD}^{+}$and $\mathrm{CD} 8^{+} \mathrm{T}$ cells (15-19). Since the approval of immune checkpoint inhibitor therapies, such as the application of PD-1 and CTLA-4 antibodies, several clinical studies have been conducted worldwide on the effects of these treatments on various types of cancer, including colorectal and thyroid cancers and lymphoid malignancies (20-22). In addition, immune-suppressive cells, such as myeloid-derived suppressor cells (MDSC) and regulatory T cells (Treg) do not trigger the activation and/or proliferation of effector $\mathrm{T}$ cells and thereby escape the immune response $(23,24)$. Previous studies have shown higher quantities of MDSCs to be associated with poor outcomes in patients with certain solid tumors, such as colon cancer, melanoma, hepatocellular carcinoma and breast cancer (25-28). These studies were conducted using patient peripheral blood samples. Serial collection of tumor samples from patients with metastatic sarcoma is usually difficult. Therefore, the use of peripheral blood samples, which can be collected with minimally invasive methods, will be extremely valuable for the identification of potential biomarker candidates.

The immunological status (the number of immune cell subsets, such as T and B cells, NK cells and immuno-suppressive cells, as well as those corresponding to cells secreting immune checkpoint molecules) for patients with bone sarcoma and STS remain uncertain. In the present study, the immunological status of patients with bone sarcoma and STS was assessed in peripheral blood samples. The results provide more information on the host immune reaction against sarcoma based on analysis of T-cell expression in response to co-stimulation with activated molecules.

\section{Materials and methods}

Patients. Following institutional review board approval (approval no. 2014-287), the patients who were treated at the National Cancer Center Hospital (Tokyo, Japan) between April 2015 and March 2017 were prospectively enrolled. In total, 86 patients were enrolled, of which 61 patients had no metastasis of high-grade sarcoma and 25 patients presented with metastatic sarcoma. No metastasis was defined as stages I-III and metastatic sarcoma as stage IV. The characteristics of the patients are summarized in Table I. The patients provided written informed consent. The patients who met the following exclusion criteria were not enrolled in the study: i) Subjects under 15 years of age, ii) the presence of active viral infections, such as human immunodeficiency virus or hepatitis $\mathrm{B}$ and/or hepatitis $\mathrm{C}$, and iii) ongoing treatment with steroids.

Clinicopathological factors and staining of peripheral blood mononuclear cells (PBMCs). The peripheral blood samples were collected prior to treatment, including surgery and chemotherapy. Levels of alkaline phosphatase (ALP), C-reactive protein (CRP) and lactate dehydrogenase (LDH), white blood count and differential count of leukocytes, including lymphocytes, neutrophils, monocytes and eosinocytes were analyzed. The blood samples were centrifuged at $425 \mathrm{x} g$ for $10 \mathrm{~min}$ at room temperature, using density gradient centrifugation, and the separated plasma samples were cryopreserved at $-80^{\circ} \mathrm{C}$ in cryogenic tubes (Thermo Fisher Scientific, Inc.) using CELLBANKER (Nippon Zenyaku Kogyo). Fresh PBMC samples were stained for the myeloid cell subset, since the MDSC fraction was decreased by cryopreservation (29). Each sample was also stained for the subset of dendritic cells (DC) concomitantly with MDSC measurement, since a common flow cytometry panel was used for both of these cell subsets. The remaining PBMCs were cryopreserved and used for measurements of T, B and NK cell subsets.

PBMCs $\left(5 \times 10^{5}\right)$ were suspended in $100 \mathrm{ml}$ staining buffer (PBS containing 2\% FBS (Sigma-Aldrich; Merck KGaA). The antibodies for the surface markers were subsequently added followed by a 30 -min incubation period at $4^{\circ} \mathrm{C}$. The staining of the intracellular proteins (LAG-3 and FOXP3) was performed using the Foxp3/Transcription Factor Fixation/ Permeabilization Concentrate and Diluent with a 30-min incubation at $4^{\circ} \mathrm{C}$ (cat. no. 12-4777-42; eBioscience; Thermo Fisher Scientific, Inc.) according to the manufacturer's protocol. The antibodies used were as follows: Lineage (Lin; CD3, CD16, CD19, CD20 and CD56) cocktail FITC (cat. no. 643397; BD Pharmingen; BD Biosciences), LAG-3 FITC (cat. no. ALX-804-806F-C100; Enzo Life Sciences, Inc.), OX-40 FITC (cat. no. 55837; BD Pharmingen; BD Biosciences), CD14 peridinin chlorophyll protein (PerCP)-Cy5.5 (cat. no. 561116; BD Pharmingen; BD Biosciences,), CD28 PerCP-cy5.5 (cat. no. 337181; BD Pharmingen; BD Biosciences), CD11b allophycocyanin (APC)-Cy7 (cat. no. 557754; BD Pharmingen; BD Biosciences), CD8 APC-Cy7 (cat. no. 557834; BD Pharmingen; BD Biosciences), CD33-phycoerythrin (PE)-Cy7 (cat. no. 333946; BD Pharmingen; BD Biosciences), ICOS PE-Cy7 (cat. no. 25-9948-42; eBioscience; Thermo Fisher Scientific, Inc.), NKG2D PE-Cy7 (cat. no. 320812; BioLegend, Inc.), CD11c Alexa Fluor700 (cat. no. 561352; BD Pharmingen; BD Biosciences), CD45RA Alexa Fluor700 (cat. no. 304120; BioLegend, Inc.), CD123 Brilliant Violet 421 (cat. no. 562517; BD Pharmingen; BD Biosciences), CD62-L (cat. no. 304828; BioLegend, Inc.), CD15 V500 (cat. no. 561585; BD Pharmingen; BD Biosciences), CD66b APC (cat. no. 561645; BD Pharmingen; BD Biosciences), PD-1 APC (cat. no. 558694; BD Pharmingen; BD Biosciences), NKG2A APC (cat. no. PN A60797; Beckman Coulter, Inc.), 
Table I. Clinicopathological characteristics of the patients with bone and soft-tissue sarcoma, and with and without metastasis

\begin{tabular}{|c|c|c|c|c|}
\hline \multirow{2}{*}{$\begin{array}{l}\text { Clinicopathological } \\
\text { characteristic }\end{array}$} & \multicolumn{2}{|c|}{$\begin{array}{c}\text { Free of metastasis and } \\
\text { high-grade sarcoma }(n=61)\end{array}$} & \multicolumn{2}{|c|}{ Metastatic sarcoma $(\mathrm{n}=25)$} \\
\hline & Value & Percentage & Value & Percentage \\
\hline $\begin{array}{l}\text { Median age } \\
\text { (range), years }\end{array}$ & $56(19-83)$ & & $60.1(24-77)$ & \\
\hline \multicolumn{5}{|l|}{ Sex } \\
\hline Male & 39 & 65.0 & 14 & 56.0 \\
\hline Female & 22 & 35.0 & 11 & 44.0 \\
\hline \multicolumn{5}{|l|}{ PS } \\
\hline 0 & 44 & 72.1 & 9 & 36.0 \\
\hline 1 & 17 & 27.9 & 8 & 32.0 \\
\hline 2 & & & 5 & 20.0 \\
\hline 3 & & & 2 & 8.0 \\
\hline 4 & & & 1 & 4.0 \\
\hline \multicolumn{5}{|l|}{ Location } \\
\hline Bone & 15 & & 5 & \\
\hline Femur & 7 & 46.6 & 4 & 16.0 \\
\hline Rib & 3 & 20.0 & & \\
\hline Tibia & 2 & 13.3 & & \\
\hline Scapula & 1 & 6.7 & & \\
\hline Radius & 1 & 6.7 & & \\
\hline Sacrum & 1 & 6.7 & & \\
\hline Toe & & & 1 & 4.0 \\
\hline Soft tissue & 46 & & 20 & \\
\hline Femur & 16 & 34.7 & 3 & 12.0 \\
\hline Retroperitoneum & 8 & 17.3 & 4 & 16.0 \\
\hline Lower leg & 6 & 13.1 & 3 & 12.0 \\
\hline Axilla & 3 & 6.5 & 6 & 24.0 \\
\hline Neck & 1 & 2.2 & 1 & 4.0 \\
\hline Back & 2 & 4.4 & 1 & 4.0 \\
\hline Forearm & 2 & 4.4 & & \\
\hline Shoulder & 2 & 4.4 & & \\
\hline Foot & 1 & 2.2 & & \\
\hline Humerus & 1 & 2.2 & & \\
\hline Inguinal & 1 & 2.2 & & \\
\hline Knee & 1 & 2.2 & & \\
\hline Buttocks & 2 & 4.4 & & \\
\hline Chest wall & & & 1 & 4.0 \\
\hline Pelvis & & & 1 & 4.0 \\
\hline \multicolumn{5}{|l|}{ Sarcoma } \\
\hline Liposarcoma & 15 & 24.6 & 6 & 24.0 \\
\hline Myxoid LS & 7 & & 2 & \\
\hline Dedifferentiated LS & 6 & & 1 & \\
\hline Pleomorphic LS & 2 & & 3 & \\
\hline UPS & 9 & 14.8 & 4 & 16.0 \\
\hline $\mathrm{OS}$ & 9 & 14.8 & 4 & 16.0 \\
\hline Myxofibrosarcoma & 8 & 13.1 & 1 & 4.0 \\
\hline MPNST & 6 & 9.8 & 3 & 12.0 \\
\hline Chondrosarcoma & 5 & 8.3 & 1 & 4.0 \\
\hline Synovial sarcoma & 3 & 4.9 & 2 & 8.0 \\
\hline Epithelioidsarcoma & 2 & 3.3 & & \\
\hline Angiosarcoma & 1 & 1.6 & & \\
\hline
\end{tabular}


Table I. Continued.

\begin{tabular}{|c|c|c|c|c|}
\hline \multirow{2}{*}{$\begin{array}{l}\text { Clinicopathological } \\
\text { characteristic }\end{array}$} & \multicolumn{2}{|c|}{$\begin{array}{l}\text { Free of metastasis and } \\
\text { high-grade sarcoma }(n=61)\end{array}$} & \multicolumn{2}{|c|}{ Metastatic sarcoma $(n=25)$} \\
\hline & Value & Percentage & Value & Percentage \\
\hline Fibrosarcoma & 1 & 1.6 & & \\
\hline Leiomyosarcoma & 1 & 1.6 & 2 & 8.0 \\
\hline Myxofibrosarcoma & & & 1 & 4.0 \\
\hline Malignant rhabdoid tumor & & & 1 & 4.0 \\
\hline Rhabdomyosarcoma & & & 1 & 4.0 \\
\hline Malignant perineurolima & 1 & 1.6 & & \\
\hline \multicolumn{5}{|l|}{ TNM stage } \\
\hline IIA & 5 & 8.2 & & \\
\hline IIB & 9 & 14.8 & & \\
\hline III & 47 & 77.0 & & \\
\hline IV & & & 25 & 100 \\
\hline
\end{tabular}

PS, performance stage; LS; liposarcoma; UPS, undifferentiated pleomorphic sarcoma; OS, osteosarcoma; MPNST, malignant peripheral nerve sheath tumor.

HLA-DR ECD (cat. no. PN IM3636; Beckman Coulter, Inc.), CD56 PE-CF 594 (cat. no. 562289; BD Pharmingen; BD Biosciences), FOXP3 PE (cat. no. 12-4777-42; eBioscience, Thermo Fisher Scientific, Inc.), CD16 BUV395 (cat. no. 563785; BD Pharmingen; BD Biosciences), CD3 BUV496 (cat. no. 564809; BD Pharmingen; BD Biosciences), CD4 Brilliant Violet 650 (cat. no. 317436; BioLegend, Inc.), CCR7 BV711 (cat. no. 353228; BioLegend, Inc.), 4-1BB BV711 (cat. no. 740798; BD Pharmingen; BD Biosciences), CTLA-4 BV786 (cat. no. 563931; BD Pharmingen; BD Biosciences), Tim-3 BV786 (cat. no. 345032; BioLegend, Inc.) and CD19 PE-Cy5.5 (cat. no. 35-0198-42; eBioscience, Thermo Fisher Scientific, Inc.). Isotype controls included the appropriate fluorochrome-conjugate as follows: Brilliant violet 421 mouse IgG1, $\kappa$ isotype control (cat. no. 400158; BioLegend, Inc.), brilliant violet 711 mouse IgG2a, $\kappa$ isotype control (cat.

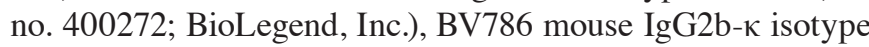
control (cat. no. 563732; BD Pharmingen; BD Biosciences), FITC mouse IgG1, $\kappa$ isotype control (cat. no. 400108; BioLegend, Inc.), PerCP-Cy5.5 mouse IgG1 $\kappa$ isotype control (cat. no. 45-4714-82; eBioscience), PE mouse IgG1 $\kappa$ isotype control (cat. no. 12-4714-82; eBioscience), PE-Cy7 mouse IgG1 $\kappa$ isotype control (cat. no. 25-4714-42; eBioscience), APC mouse IgG1 $\kappa$ isotype control (cat. no. 555751; eBioscience), brilliant violet 711 mouse IgG1, $\kappa$ isotype control (cat. no. 400168 ; BioLegend, Inc.) and brilliant violet $785^{\mathrm{TM}}$ mouse IgG1, $\kappa$ isotype control (cat. no. 400170; BioLegend, Inc.).

The stained cells were detected using an LSR Fortessa X-20 with the FACSDiva software (BD Biosciences). The analyses were performed using a FlowJo microplate reader (Tomy Digital Biology Co., Ltd.).

Definition and analysis of the immune cell subsets. A total of 41 immune cell subsets were analyzed in the present study. They were defined as follows: Monocytic-MDSCs (M-MDSCs): Lin-CD14 ${ }^{+} \mathrm{CD} 33^{+} \mathrm{CD} 11 \mathrm{~b}^{+}$HLA-DR ${ }^{\mathrm{low} /}$; granulocytic MDSCs
(Gr-MDSCs): CD33 ${ }^{\mathrm{dim}} \mathrm{CD} 15^{+} \mathrm{CD} 66^{+} \mathrm{CD} 11 \mathrm{~b}^{+}$; Myeloid DCs (M-DCs): Lin-CD14-CD11 $\mathrm{c}^{+} \mathrm{HLADR}^{\text {high}}$; plasmacytoid DCs (p-DCs): Lin-CD14-CD123+HLA-DR ${ }^{\text {high }}$; naive T-regs: $\mathrm{CD} 3{ }^{+} \mathrm{CD} 4^{+} \mathrm{CD} 45 \mathrm{RA}-\mathrm{FOXP} 3^{\text {high }}$; and effector T-regs: $\mathrm{CD}^{+}{ }^{+} \mathrm{CD} 4^{+} \mathrm{CD} 45 \mathrm{RA}^{+} \mathrm{FOXP} 3^{\text {high }}$. $\mathrm{T}$ cells were classified as naïve $\mathrm{T}$ cells $\left(\mathrm{CD} 45 \mathrm{RA}^{+} \mathrm{CCR} 7^{+}\right)$, effector $\mathrm{T}$ cells $\left(\mathrm{CD} 45 \mathrm{RA}^{+} \mathrm{CCR} 7^{-}\right)$, effector memory T cells (CD45RA-CCR7 ${ }^{-}$) and central memory T cells $\left(\mathrm{CD} 45 \mathrm{RA}^{-} \mathrm{CCR} 7^{+}\right)$, in populations of $\mathrm{CD}^{+}$or $\mathrm{CD} 8^{+}$ cells (Fig. 1). NK cells were classified as CD56 $6^{\text {bright }} \mathrm{NK}$ cells $\left(\mathrm{CD} 3^{-\mathrm{CD}} 19^{-} \mathrm{CD} 14^{-} \mathrm{CD} 16^{+} \mathrm{CD} 56^{\text {bright }}\right)$ and $\mathrm{CD} 56^{\mathrm{dim}} \mathrm{NK}$ cells $\left(\mathrm{CD} 3{ }^{-} \mathrm{CD} 19^{-} \mathrm{CD} 14^{-} \mathrm{CD} 16^{+} \mathrm{CD} 56^{\mathrm{dim}}\right)$. The quantities of $\mathrm{CD} 28$, 4-1BB, ICOS, OX-40, CTLA-4, PD-1, Tim-3, LAG-3, NKG2D, NKG2A and CD62-L were also assessed in $\mathrm{CD}^{+}$and $\mathrm{CD} 8^{+}$ $\mathrm{T}$ cells and NK cells (Figs. 2 and 3). Isotype controls were used to determine the cut-off levels for distinguishing between positivity and negativity. The quantities of the lymphoid subsets were obtained by dividing the cell number of each subset by the cell number of the lymphocyte fraction, based on the results obtained from the flow cytometry analysis. The quantities of Gr-MDSCs were calculated by dividing the cell number of $\mathrm{CD} 33^{\mathrm{dim}} \mathrm{CD} 15^{+} \mathrm{CD} 66^{+} \mathrm{CD} 11 \mathrm{~b}^{+}$cells by the number of PBMCs. The patients were divided, based on the median values, according to the proportion of each immune cell subset into elevated and non-elevated groups.

Statistical analysis. In the present study, DFS was defined follows: From the day of study registration and blood collection after the primary treatment for tumor ended until the day of confirmation of a new lesion or symptom of the tumor. PFS was defined follows: From the day of study registration and blood collection after the treatment of a disease until the day of confirmation of disease progression. Imaging studies, such as CT scans, were performed approximately every three months to check for disease progression and the appearance of new lesions, and was assessed according to the Response Evaluation Criteria in Solid Tumors guidelines (v1.1) (30). The 


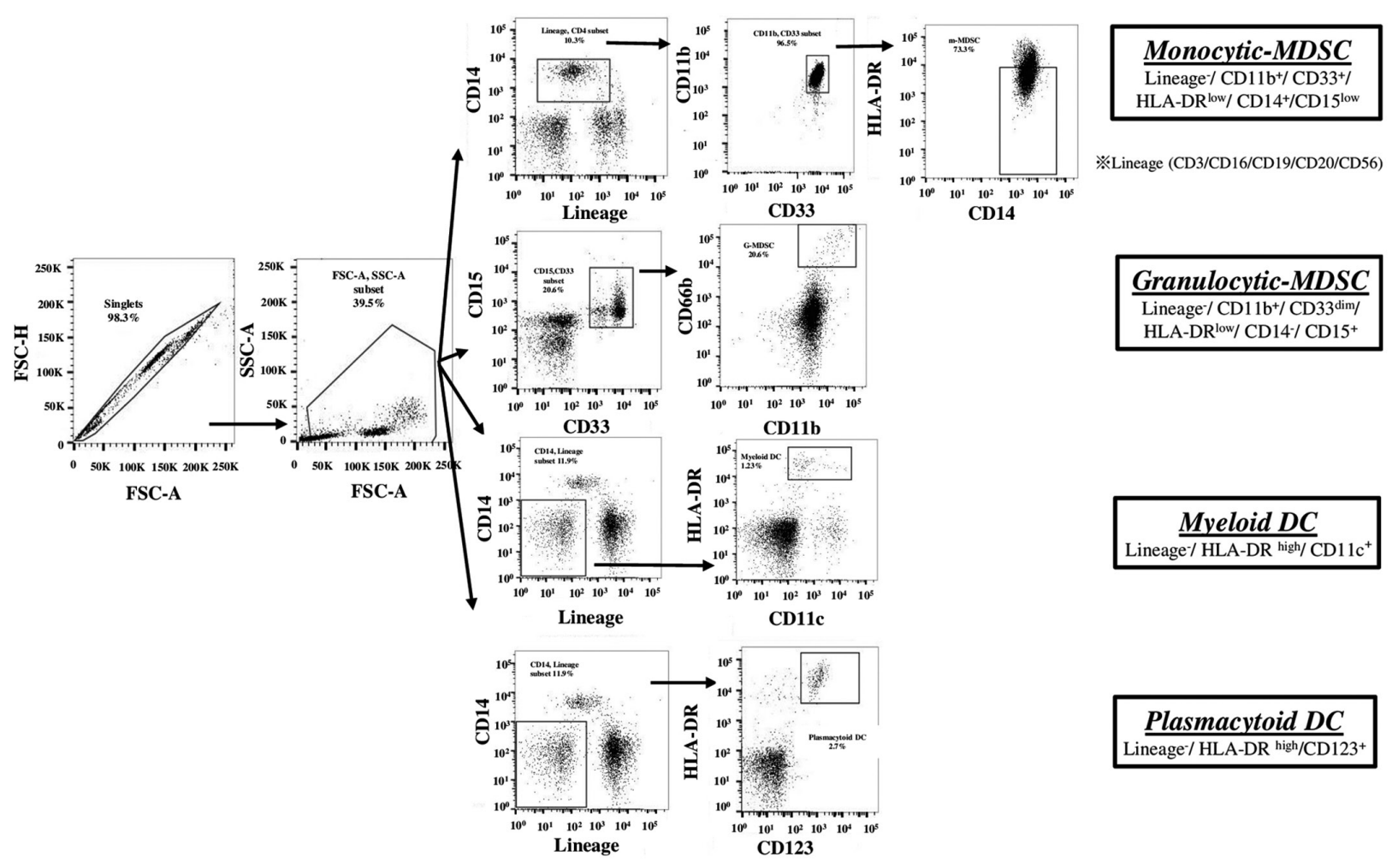

Figure 1. Gating strategy for the immune suppressor cells and antigen-presenting cells. Gating strategy and representative dot plots for M-MDSCs, Gr-MDSCs,

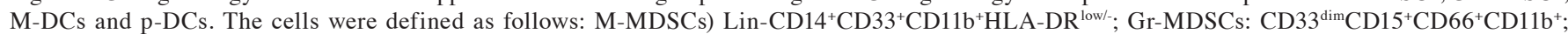
M-DC: Lin-CD14-CD11 ${ }^{+} \mathrm{HLA}^{-} \mathrm{RR}^{\text {high }}$; p-DC: Lin-CD14-CD123+HLA-DR ${ }^{\text {high }}$. MDSCs, myeloid-derived suppressor cells; M-MDSCs, monocytic-MDSCs; Gr-MDSCs, granulocytic MDSCs; DCs, dendritic cells; M-DCs, myeloid DCs; p-DCs, plasmacytoid DCs.

data are presented as the mean $\pm \mathrm{SD}$. The association between clinicopathological factors, and the different immune cell subsets with DFS and PFS were analyzed using univariate logistic analysis. The patients were divided into elevated and non-elevated groups based on the median values and according to the proportion of each immune cell subset. The DFS and PFS curves were calculated using the Kaplan-Meier method and compared with the log-rank test. Pearson's correlation was used to evaluate for correlations between each pair of immune cell subset. Multivariate cox regression analysis was used to investigate the association between clinicopathological factors and DFS. $\mathrm{P}<0.05$ was considered to indicate a statistically significant difference. Statistical analyses were performed using the GraphPad Prism software (v7; GraphPad Software, Inc.) and the SPSS statistical software (v21.0; IBM Corp.). The experiments were repeated three times.

\section{Results}

Quality of immune cell subsets in patients with bone sarcoma and STS. Each immune cell subset was detected using flow cytometry. The median values of the proportion and range in patients with high-grade non-metastatic are shown in Table SI. In addition, the median values of the proportion and range of the patients with metastatic sarcoma are shown in Table SII.

Associations between clinicopathological factors/number of suppressor cells and number of antigen-presenting cells/ effector cells/cells secreting immune checkpoint proteins and DFS/PFS. A total of 61 patients with no metastasis and high-grade sarcoma, and 25 patients with metastatic sarcoma were examined. The associations between clinicopathological factors and DFS/PFS times are shown in Table II. The patients were divided into elevated and non-elevated groups based on the median value of each factor. No significant differences were noted between the DFS time in patients without metastasis and PFS time in patients with metastasis. The gating strategies for suppressor, antigen-presenting and effector cells are shown in Figs. 1 and 2. The associations between the quantities of these cell types and the DFS time in patients without metastasis and the PFS time in patients with metastasis are shown in Tables III and IV. The patients were divided into elevated and non-elevated groups based on the median values and according to the proportion of each immune cell subset. The DFS time in patients without metastasis and the PFS time in patients with metastasis were compared between each pair of immune cell subsets. High M-MDSC number was significantly associated with lower DFS time in patients without metastasis and PFS time in patients with metastasis. The gating strategies used to determine the expression levels of molecules, such as immune checkpoint proteins, in $\mathrm{CD}^{+}{ }^{+} \mathrm{T}, \mathrm{CD}^{+} \mathrm{T}$ and $\mathrm{NK}$ cells are shown in Figs. 2 and 3. There were 65.9 and $10.2 \%$ of the $\mathrm{NKG}_{2} \mathrm{D}^{+} \mathrm{CD}^{+} \mathrm{T}$ cells, and 0.42 and $23.7 \%$ of the Tim- $3^{+}$ $\mathrm{CD}^{+} \mathrm{T}$ cells in patient nos. 60 and 49. The associations between the expression levels of these molecules and DFS time in patients without metastasis and PFS time in patients with metastasis are shown in Tables III and IV. The patients were divided, based on the median values of the immune cell subsets, into elevated and non-elevated groups. DFS 


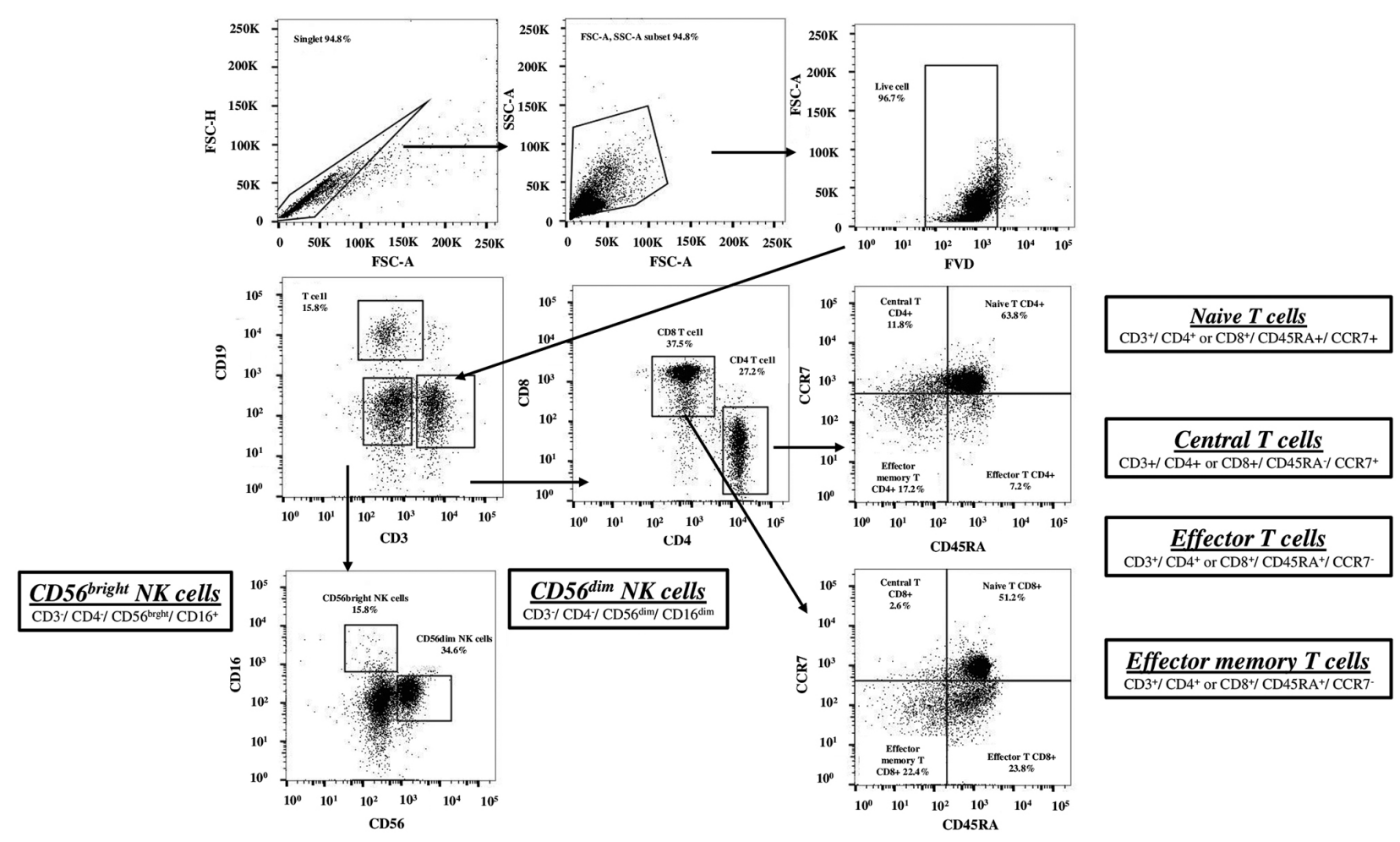

Figure 2. Gating strategy for T and NK cells. Gating strategy and representative dot plots for T and NK cells. The cells were defined as follows: $\mathrm{T}$ cells were classified as naïve $\mathrm{T}$ cells $\left(\mathrm{CD} 45 \mathrm{RA}^{+} \mathrm{CCR} 7^{+}\right)$, central memory $\mathrm{T}$ cells $\left(\mathrm{CD}^{2} 5 \mathrm{RA} \mathrm{A}^{+} \mathrm{CCR} 7^{-}\right)$, effector memory $\mathrm{T}$ cells $\left(\mathrm{CD}^{-} \mathrm{RRA}^{-} \mathrm{CCR} 7^{-}\right)$and central memory T cells $\left(\mathrm{CD} 45 \mathrm{RA}^{-} \mathrm{CCR} 7^{+}\right)$, in populations of $\mathrm{CD}^{+}{ }^{+}$or $\mathrm{CD} 8^{+}$cells. $\mathrm{NK}$ cells were classified as $\mathrm{CD} 56^{\text {bright }} \mathrm{NK}$ cells $\left(\mathrm{CD} 3{ }^{-} \mathrm{CD} 19^{-} \mathrm{CD} 14^{-} \mathrm{CD} 16^{+} \mathrm{CD} 56^{\text {bright }}\right)$ and

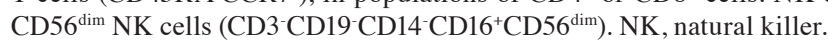
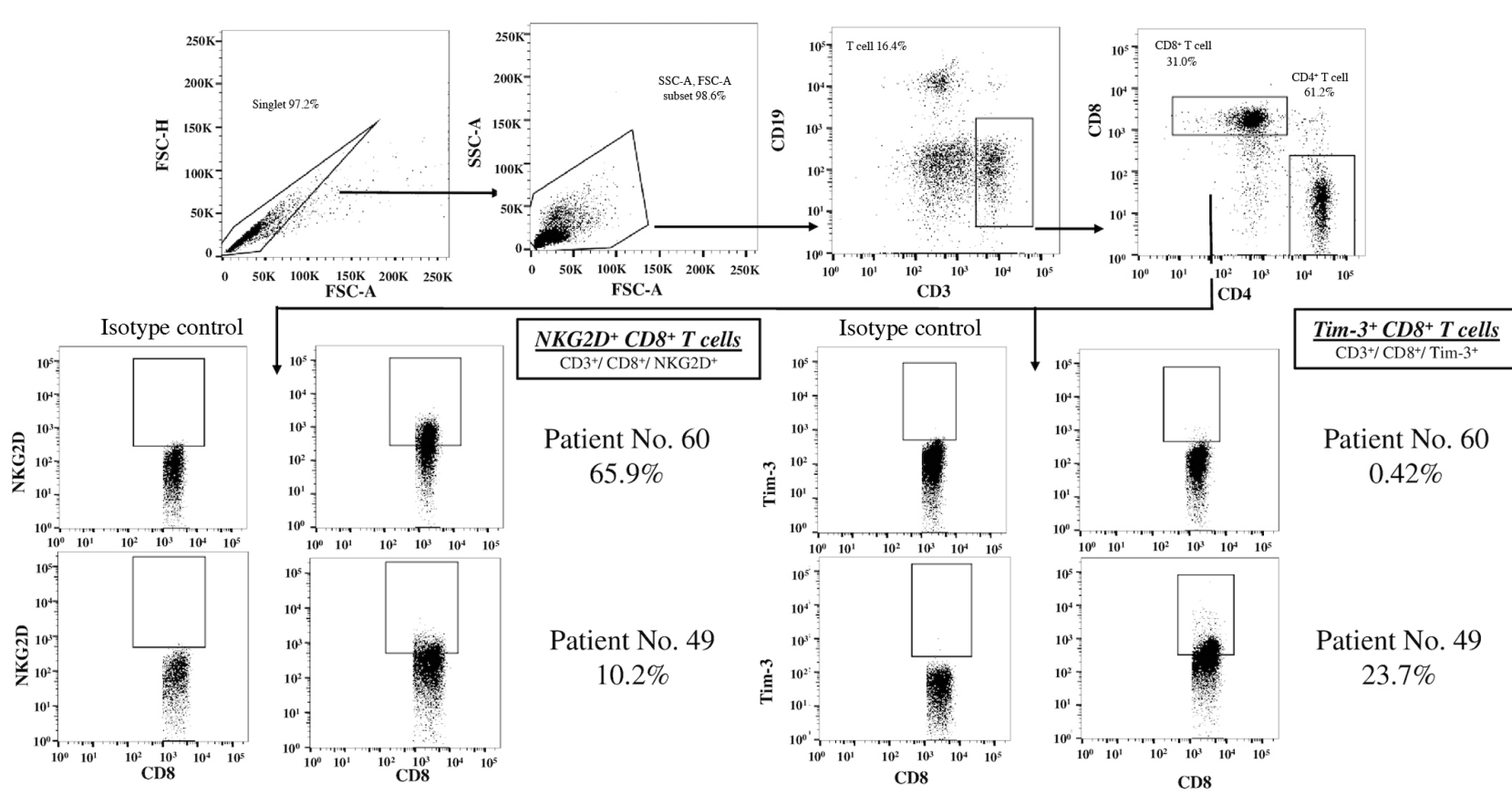

Figure 3. Gating strategy for NKG2D ${ }^{+} \mathrm{CD} 8^{+} \mathrm{T}$ and Tim- $-3^{+} \mathrm{CD} 8^{+} \mathrm{T}$ cells. Gating strategy and representative dot plots for $\mathrm{NKG} 2 \mathrm{D}^{+} \mathrm{CD} 8^{+} \mathrm{T}$ cells and Tim- $-3^{+}$ $\mathrm{CD} 8^{+} \mathrm{T}$ cells. A total of 2 independent dot plots are shown as high and low NKG2D+ $\mathrm{CD} 8^{+} \mathrm{T}$ cells, and high and low Tim- $3^{+} \mathrm{CD} 8^{+} \mathrm{T}$ cells. Isotype controls were used to determine the cut-off levels for distinguishing between positivity and negativity. NKG2D, natural killer group 2 member A; Tim-3, T cell immunoglobulin and mucin domain-3.

time in patients without metastasis and PFS time in patients with metastasis were compared between molecules, such as immune checkpoint proteins on $\mathrm{CD} 4^{+} \mathrm{T}, \mathrm{CD} 8^{+} \mathrm{T}$ and $\mathrm{B}$ cells. Low numbers of NKG2 $\mathrm{D}^{+} \mathrm{CD} 8^{+} \mathrm{T}$ cells and high numbers of Tim- $3^{+} \mathrm{CD} 8^{+} \mathrm{T}$ cells were significantly associated with lower DFS time in patients without metastasis. However, no significant differences were noted in comparisons of PFS time in patients with metastasis between two groups. 
Table II. Association between the clinicopathological factors and DFS and PFS.

\begin{tabular}{|c|c|c|c|c|}
\hline \multirow[b]{2}{*}{ Clinicopathological factors } & \multicolumn{2}{|c|}{$\begin{array}{c}\text { Free of metastasis and } \\
\text { high-grade sarcoma }(\mathrm{N}=61)\end{array}$} & \multicolumn{2}{|c|}{ Metastatic sarcoma $(\mathrm{N}=25)$} \\
\hline & HR (95\% CI) & P-value & HR $(95 \% \mathrm{CI})$ & P-value \\
\hline \multicolumn{5}{|l|}{ Age, years } \\
\hline$<56$ & Reference & & Reference & \\
\hline$\geq 56$ & $0.9(0.3-2.6)$ & 0.96 & $2.1(0.8-3.4)$ & 0.71 \\
\hline \multicolumn{5}{|l|}{ Sex } \\
\hline Male & Reference & & Reference & \\
\hline Female & $1.0(0.3-3.0)$ & 0.87 & $0.4(0.4-3.7)$ & 0.55 \\
\hline \multicolumn{5}{|l|}{ PS } \\
\hline 0 & Reference & & & \\
\hline 1 & $1.1(0.2-5.1)$ & 0.88 & & \\
\hline $0-1$ & & & Reference & \\
\hline $2-4$ & & & $2.2(0.3-3.3)$ & 0.43 \\
\hline \multicolumn{5}{|l|}{ ALP, U/l } \\
\hline$<322$ & Reference & & Reference & \\
\hline$\geq 322$ & $1.5(0.4-5.7)$ & 0.52 & $2.3(0.7-5.5)$ & 0.43 \\
\hline \multicolumn{5}{|l|}{$\mathrm{LDH}, \mathrm{U} / 1$} \\
\hline$<222$ & Reference & & Reference & \\
\hline$\geq 222$ & $3.3(0.8-12.3)$ & 0.08 & $4.3(0.6-7.3)$ & 0.66 \\
\hline \multicolumn{5}{|l|}{$\mathrm{WBC}, \mu \mathrm{l}$} \\
\hline$<8600$ & Reference & & Reference & \\
\hline$\geq 8600$ & $2.1(0.6-7.2)$ & 0.25 & $2.3(0.8-4.2)$ & 0.39 \\
\hline \multicolumn{5}{|l|}{ Lymphocytes, \% } \\
\hline$<38.9$ & Reference & & Reference & \\
\hline$\geq 38.9$ & $0.1(0-2.3)$ & 0.77 & $0.5(0.5-2.6)$ & 0.29 \\
\hline \multicolumn{5}{|l|}{ Neutrophils, \% } \\
\hline$<72.7$ & Reference & & Reference & \\
\hline$\geq 72.7$ & $2.4(0.9-7.0)$ & 0.09 & $5.2(0.4-6.1)$ & 0.12 \\
\hline \multicolumn{5}{|l|}{ Monocyte, \% } \\
\hline$<8.7$ & Reference & & Reference & \\
\hline$\geq 8.7$ & $1.0(0.1-10.9)$ & 0.95 & $3.6(0.2-6.9)$ & 0.55 \\
\hline \multicolumn{5}{|l|}{ Eosinocyte, \% } \\
\hline$<5.0$ & Reference & & Reference & \\
\hline$\geq 5.0$ & $0.1(0.1-2.4)$ & 0.78 & $0.3(0.3-2.9)$ & 0.33 \\
\hline \multicolumn{5}{|l|}{ CRP, mg/dl } \\
\hline$<0.14$ & Reference & & Reference & \\
\hline$\geq 0.14$ & $1.9(0.6-5.5)$ & 0.23 & $7.9(0.9-8.9)$ & 0.41 \\
\hline
\end{tabular}

Association of the number of M-MDSC, NKG2D $D^{+} C D 8^{+}$ $T$ cells and Tim- $3^{+} C D 8^{+} T$ cells with DFS. The association between the number of immune subset cells with DFS times in patients without metastasis was investigated. The patients were divided into 'elevated' and 'non-elevated' groups. The cut-off/threshold value was used based on the median value of immune subset cells. The data indicated that the number of M-MDSC, $\mathrm{NKG}_{2} \mathrm{D}^{+} \mathrm{CD} 8^{+} \mathrm{T}$ cells and
Tim $-3^{+} \mathrm{CD} 8^{+} \mathrm{T}$ cells was significantly associated with DFS based on the Kaplan-Meier method and the comparisons performed using the log-rank test (Fig. 4). High numbers of M-MDSC and Tim- $3^{+} \mathrm{CD} 8^{+} \mathrm{T}$ cells were significantly associated with poor DFS times $(\mathrm{P}=0.04$ and 0.02 , respectively), while high levels of $\mathrm{NKG}^{2} \mathrm{D}^{+} \mathrm{CD} 8^{+} \mathrm{T}$ cells were significantly associated with longer DFS times $(\mathrm{P}=0.04)$. Multivariate Cox regression analysis revealed that the 
Table III. Association between the quantity of each immune cell subset and disease-free survival in patients with highgrade sarcoma and without metastasis.

\begin{tabular}{|c|c|c|c|c|c|c|c|}
\hline \multirow{2}{*}{\multicolumn{4}{|c|}{$\begin{array}{l}\text { cell subset and disease-free survival in patients with high- } \\
\text { grade sarcoma and without metastasis. }\end{array}$}} & \multirow{2}{*}{\multicolumn{2}{|c|}{$\begin{array}{cc} & \text { Median, } \\
\text { Immune cell subset } & \%\end{array}$}} & \multirow[b]{2}{*}{$\begin{array}{c}\mathrm{HR} \\
(95 \% \mathrm{CI})\end{array}$} & \multirow[b]{2}{*}{ P-value } \\
\hline & & & & & & & \\
\hline \multirow[t]{2}{*}{ Immune cell subset } & $\begin{array}{l}\text { Median, } \\
\%\end{array}$ & $\begin{array}{c}\mathrm{HR} \\
(95 \% \mathrm{CI})\end{array}$ & P-value & \multirow[t]{2}{*}{ 4-1BB } & $\leq 20.3$ & Reference & \\
\hline & & & & & $>20.3$ & $2.6(0.5-13.3)$ & 0.24 \\
\hline \multirow{3}{*}{$\begin{array}{l}\text { Suppressor cells } \\
\text { M-MDSC }\end{array}$} & & & & \multirow[t]{2}{*}{ ICOS } & $\leq 3.26$ & Reference & \\
\hline & $\leq 21.4$ & Reference & & & $>3.26$ & $0.8(0.3-2.2)$ & 0.65 \\
\hline & $>21.4$ & $2.9(1.0-8.4)$ & $0.04^{\mathrm{a}}$ & $\mathrm{OX}-40$ & $\leq 0.35$ & Reference & \\
\hline \multirow[t]{2}{*}{ Gr-MDSC } & $\leq 0.04$ & Reference & & & $>0.35$ & $1.4(0.4-5.1)$ & 0.59 \\
\hline & $>0.04$ & $1.5(0.5-4.3)$ & 0.41 & CTLA-4 & $\leq 1.03$ & Reference & \\
\hline \multirow[t]{2}{*}{ Naïve Tregs } & $\leq 0.31$ & Reference & & & $>1.03$ & $0.4(0.1-1.1)$ & 0.07 \\
\hline & $>0.31$ & $0.9(0.3-2.7)$ & 0.94 & PD-1 & $\leq 0.11$ & Reference & \\
\hline \multirow[t]{2}{*}{ Effector Tregs } & $\leq 0.01$ & Reference & & & $>0.11$ & $0.7(0.2-2.0)$ & 0.50 \\
\hline & $>0.01$ & $0.7(0.2-2.0)$ & 0.50 & LAG-3 & $\leq 0.08$ & Reference & \\
\hline \multirow{3}{*}{$\begin{array}{l}\text { Antigen-presenting cells } \\
\text { Myeloid DC }\end{array}$} & & & & & $>0.08$ & $0.5(0.17-1.4)$ & 0.19 \\
\hline & $\leq 0.31$ & Reference & & Tim-3 & $\leq 5.8$ & Reference & \\
\hline & $>0.31$ & $1.5(0.5-4.4)$ & 0.44 & & $>5.8$ & $1.3(0.3-5.4)$ & 0.72 \\
\hline \multirow[t]{2}{*}{ Plasmacytoid DC } & $\leq 0.22$ & Reference & & NKG2D & $\leq 10.2$ & Reference & \\
\hline & $>0.22$ & $0.9(0.3-2.6)$ & 0.91 & & $>10.2$ & $2.9(0.8-11.9)$ & 0.12 \\
\hline \multirow{3}{*}{$\begin{array}{l}\text { Effector cells } \\
\mathrm{CD}^{+} \mathrm{T} \text { cells }\end{array}$} & & & & NKG2A & $\leq 0.14$ & Reference & \\
\hline & $\leq 35.5$ & Reference & & & $>0.14$ & $2.2(0.7-7.7)$ & 0.19 \\
\hline & $>35.5$ & $1.0(0.4-3.1)$ & 0.89 & CD62-L & $\leq 16.7$ & Reference & \\
\hline \multirow[t]{2}{*}{ Naïve } & $\leq 15.4$ & Reference & & & $>16.7$ & $0.3(0.1-1.0)$ & 0.06 \\
\hline & $>15.4$ & $1.0(0.4-3.0)$ & 0.94 & Expression on $\mathrm{CD}^{+}$ & & & \\
\hline \multirow[t]{2}{*}{ Effector } & $\leq 20.2$ & Reference & & $\mathrm{T}$ cells & & & \\
\hline & 20.2 & $2.2(0.7-6.8)$ & 0.16 & CD28 & $\leq 0.11$ & Reference & \\
\hline \multirow[t]{2}{*}{ Effector memory } & $\leq 28.9$ & Reference & & & $>0.11$ & $0.5(0.17-1.5)$ & 0.23 \\
\hline & $>28.9$ & $0.4(0.2-1.3)$ & 0.13 & 4-1BB & $\leq 15.8$ & Reference & \\
\hline \multirow[t]{2}{*}{ Central memory } & $\leq 58.8$ & Reference & & & $>15.8$ & $15.9(0.1-4.4)$ & 0.75 \\
\hline & $>58.8$ & $0.7(0.3-2.1)$ & 0.58 & ICOS & $\leq 0.43$ & Reference & \\
\hline \multirow[t]{2}{*}{$\mathrm{CD}^{+} \mathrm{T}$ cells } & $\leq 42.8$ & Reference & & & $>0.43$ & $1.3(0.5-4.0)$ & 0.54 \\
\hline & $>42.8$ & $0.33(0.4-3.5)$ & 0.72 & OX-40 & $\leq 0.19$ & Reference & \\
\hline Naïve & $\leq 27.0$ & Reference & & & $>0.19$ & $1.6(0.5-5.3)$ & 0.38 \\
\hline & $>27.0$ & $3.0(0.9-7.8)$ & 0.60 & CTLA-4 & $\leq 0.68$ & Reference & \\
\hline Effector & $\leq 25.2$ & Reference & & & $>0.68$ & $0.4(0.2-1.3)$ & 0.15 \\
\hline & $>25.2$ & $2.9(1.0-8.9)$ & 0.12 & PD-1 & $\leq 0.39$ & Reference & \\
\hline Effector memory & $\leq 64.8$ & Reference & & & $>0.39$ & $0.3(0.4-2.3)$ & 0.21 \\
\hline & $>64.8$ & $0.4(0.1-1.1)$ & 0.07 & LAG-3 & $\leq 7.6$ & Reference & \\
\hline Central memory & $\leq 30.3$ & Reference & & & $>7.6$ & $0.5(0.2-1.5)$ & 0.21 \\
\hline & $>30.3$ & $0.7(0.2-1.9)$ & 0.47 & Tim-3 & $\leq 8.7$ & Reference & \\
\hline $\mathrm{B}$ cells & $\leq 1.05$ & Reference & & & $>8.7$ & $3.4(1.0-11.1)$ & $0.04^{\mathrm{a}}$ \\
\hline & $>1.05$ & $0.9(0.3-2.6)$ & 0.89 & NKG2D & $\leq 26.6$ & Reference & \\
\hline CD56 ${ }^{\text {bright }} \mathrm{NK}$ cells & $\leq 11.5$ & Reference & & & $>26.6$ & $0.3(0.1-0.9)$ & $0.05^{\mathrm{a}}$ \\
\hline & $>11.5$ & $1.7(0.6-4.9)$ & 0.33 & NKG2A & $\leq 1.4$ & Reference & \\
\hline CD56 ${ }^{\text {dim }}$ NK cells & $\leq 1.1$ & Reference & & & $>1.4$ & $1.6(0.5-4.8)$ & 0.41 \\
\hline & $>1.1$ & $0.6(0.2-1.7)$ & 0.33 & CD62-L & $\leq 24.7$ & Reference & \\
\hline Expression on $\mathrm{CD}^{+}$ & & & & & $>24.7$ & $0.7(0.2-2.0)$ & 0.50 \\
\hline $\begin{array}{l}\text { T cells } \\
\text { CD28 }\end{array}$ & $\begin{array}{l}\leq 0.32 \\
>0.32\end{array}$ & $\begin{array}{c}\text { Reference } \\
0.6(0.2-1.8)\end{array}$ & 0.41 & $\begin{array}{l}\text { aP }<0.05 . \text { M-MDSC, mor } \\
\text { granulocytic; DC, dendi } \\
\text { T cells. }\end{array}$ & $\begin{array}{l}\text { tic myeloic } \\
\text { cells; HR, }\end{array}$ & $\begin{array}{l}\text {-derived suppress } \\
\text { hazard ratio; Treg, }\end{array}$ & $\begin{array}{l}\text { cells; Gr, } \\
\text { egulatory }\end{array}$ \\
\hline
\end{tabular}

Table III. Continued. granulocytic; DC, dendritic cells, HR, hazard ratio; Treg, regulatory (20) 
Table IV. Association between the quantity of each immune cell subset and progression-free survival in patients with metastatic sarcoma.

\begin{tabular}{|c|c|c|c|}
\hline Immune cell subset & $\begin{array}{c}\text { Median, } \\
\%\end{array}$ & $\begin{array}{c}\mathrm{HR} \\
(95 \% \mathrm{CI})\end{array}$ & P-value \\
\hline \multicolumn{4}{|l|}{ Suppressor cells } \\
\hline \multirow[t]{2}{*}{ M-MDSC } & $\leq 44.2$ & Reference & \\
\hline & $>44.2$ & $5.9(1.3-26.7)$ & $0.02^{\mathrm{a}}$ \\
\hline \multirow[t]{2}{*}{ Gr-MDSC } & $\leq 0.63$ & Reference & \\
\hline & $>0.63$ & $0.3(0.7-1.2)$ & 0.09 \\
\hline \multirow[t]{2}{*}{ Naïve Tregs } & $\leq 0.62$ & Reference & \\
\hline & $>0.62$ & $3.2(0.5-3.5)$ & 0.34 \\
\hline \multirow[t]{2}{*}{ Effector Tregs } & $\leq 0.03$ & Reference & \\
\hline & $>0.03$ & $0.7(0.2-7.9)$ & 0.88 \\
\hline \multicolumn{4}{|c|}{ Antigen-presenting cells } \\
\hline \multirow[t]{2}{*}{ Myeloid DC } & $\leq 0.34$ & Reference & \\
\hline & $>0.34$ & $1.5(0.4-6.1)$ & 0.52 \\
\hline \multirow[t]{2}{*}{ Plasmacytoid DC } & $\leq 0.48$ & Reference & \\
\hline & $>0.48$ & $2.1(0.5-8.2)$ & 0.30 \\
\hline \multicolumn{4}{|l|}{ Effector cells } \\
\hline \multirow[t]{2}{*}{$\mathrm{CD} 4^{+} \mathrm{T}$ cells } & $\leq 29.7$ & Reference & \\
\hline & $>29.7$ & $0.5(0.1-4.3)$ & 0.53 \\
\hline \multirow[t]{2}{*}{ Naïve } & $\leq 21.8$ & Reference & \\
\hline & $>21.8$ & $0.2(0.1-1.7)$ & 0.14 \\
\hline \multirow[t]{2}{*}{ Effector } & $\leq 3.42$ & Reference & \\
\hline & $>3.42$ & $2.1(0.3-16.5)$ & 0.50 \\
\hline \multirow[t]{2}{*}{ Effector memory } & $\leq 32.4$ & Reference & \\
\hline & $>32.4$ & $0.1(0.1-1.4)$ & 0.09 \\
\hline \multirow[t]{2}{*}{ Central memory } & $\leq 33.1$ & Reference & \\
\hline & $>33.1$ & $0.3(0.1-2.4)$ & 0.23 \\
\hline \multirow[t]{2}{*}{$\mathrm{CD}^{+} \mathrm{T}$ cells } & $\leq 26.8$ & Reference & \\
\hline & $>26.8$ & $1.4(0.2-11.8)$ & 0.77 \\
\hline \multirow[t]{2}{*}{ Naïve } & $\leq 16.7$ & Reference & \\
\hline & $>16.7$ & $1.4(0.1-15.7)$ & 0.77 \\
\hline \multirow[t]{2}{*}{ Effector } & $\leq 14.6$ & Reference & \\
\hline & $>14.6$ & $5.1(0.4-2.3)$ & 0.33 \\
\hline \multirow[t]{2}{*}{ Effector memory } & $\leq 46.7$ & Reference & \\
\hline & $>46.7$ & $11.2(0.6-21.7)$ & 0.11 \\
\hline \multirow[t]{2}{*}{ Central memory } & $\leq 9.28$ & Reference & \\
\hline & $>9.28$ & $0.2(0.1-3.0)$ & 0.23 \\
\hline \multirow[t]{2}{*}{ B cells } & $\leq 8.39$ & Reference & \\
\hline & $>8.39$ & $0.3(0.1-3.9)$ & 0.36 \\
\hline \multirow[t]{2}{*}{ CD56 ${ }^{\text {bright }} \mathrm{NK}$ cells } & $\leq 13.4$ & Reference & \\
\hline & $>13.4$ & $1.2(0.2-9.0)$ & 0.83 \\
\hline \multirow[t]{2}{*}{ CD56 ${ }^{\mathrm{dim}} \mathrm{NK}$ cells } & $\leq 2.3$ & Reference & \\
\hline & $>2.3$ & $7.4(0.9-60.3)$ & 0.62 \\
\hline
\end{tabular}

Expression on $\mathrm{CD}^{+}$

T cells

CD28

$\leq 0.77 \quad$ Reference

$>0.77 \quad 0.3(0.1-3.8) \quad 0.38$
Table IV. Continued.

\begin{tabular}{|c|c|c|c|}
\hline Immune cell subset & $\begin{array}{c}\text { Median, } \\
\%\end{array}$ & $\begin{array}{c}\text { HR } \\
(95 \% \mathrm{CI})\end{array}$ & P-value \\
\hline \multirow[t]{2}{*}{$4-1 \mathrm{BB}$} & $\leq 10.2$ & Reference & \\
\hline & $>10.2$ & $1.7(0.2-12.1)$ & 0.60 \\
\hline \multirow[t]{2}{*}{ ICOS } & $\leq 4.98$ & Reference & \\
\hline & $>4.98$ & $0.3(0.1-2.1)$ & 0.19 \\
\hline \multirow[t]{2}{*}{ OX-40 } & $\leq 0.53$ & Reference & \\
\hline & $>0.53$ & $0.24(0.1-2.9)$ & 0.26 \\
\hline \multirow[t]{2}{*}{ CTLA-4 } & $\leq 1.31$ & Reference & \\
\hline & $>1.31$ & $0.3(0.1-2.4)$ & 0.25 \\
\hline \multirow[t]{2}{*}{ PD-1 } & $\leq 0.52$ & Reference & \\
\hline & $>0.52$ & $16.1(0.6-4.1)$ & 0.09 \\
\hline \multirow[t]{2}{*}{ LAG-3 } & $\leq 0.29$ & Reference & \\
\hline & $>0.29$ & $0.4(0.1-3.2)$ & 0.39 \\
\hline \multirow[t]{2}{*}{ Tim-3 } & $\leq 3.58$ & Reference & \\
\hline & $>3.58$ & $0.3(0.1-2.6)$ & 0.28 \\
\hline \multirow[t]{2}{*}{ NKG2D } & $\leq 7.9$ & Reference & \\
\hline & $>7.9$ & $0.1(0.1-1.4)$ & 0.09 \\
\hline \multirow[t]{2}{*}{ NKG2A } & $\leq 0.82$ & Reference & \\
\hline & $>0.82$ & $0.7(0.1-4.1)$ & 0.65 \\
\hline \multirow[t]{2}{*}{ CD62-L } & $\leq 53.2$ & Reference & \\
\hline & $>53.2$ & $6.0(0.2-15.2)$ & 0.28 \\
\hline
\end{tabular}

Expression on $\mathrm{CD}^{+}$

$\mathrm{T}$ cells

CD28

$\leq 0.49 \quad$ Reference

4-1BB

$>0.49 \quad 6.8(0.3-15.7) \quad 0.23$

$\leq 8.07 \quad$ Reference

$>8.07 \quad 2.3(0.4-2.8) \quad 0.33$

ICOS

$\leq 0.45 \quad$ Reference

$>0.45 \quad 1.5(0.1-24.1) \quad 0.78$

OX-40

$\leq 1.44 \quad$ Reference

$>1.44 \quad 0.3(0.3-1.8) \quad 0.55$

CTLA-4

$\leq 0.57 \quad$ Reference

$>0.57 \quad 0.4(0.4-4.1) \quad 0.46$

PD-1

$\leq 0.23 \quad$ Reference

$>0.23 \quad 2.7(0.2-32.2) \quad 0.44$

LAG-3

$\begin{array}{ccc}\leq 0.08 & \text { Reference } & \\ >0.08 & 0.2(0.1-3.7) & 0.30\end{array}$

Tim-3

$\leq 0.88$

Reference

$>0.88 \quad 2.8(0.4-9.2) \quad 0.12$

NKG2D

$\leq 15.4 \quad$ Reference

NKG2A

$\leq 3.68 \quad$ Reference

$>3.68 \quad 0.4(0.9-12.5) \quad 0.55$

CD62-L

$\leq 33.9 \quad$ Reference

$>33.9 \quad 0.1(0.1-2.7)$

0.18

${ }^{\mathrm{a}} \mathrm{P}<0.05$. M-MDSC, monocytic myeloid-derived suppressor cells; Gr, granulocytic; DC, dendritic cells; HR, hazard ratio; Treg, regulatory $\mathrm{T}$ cells. 

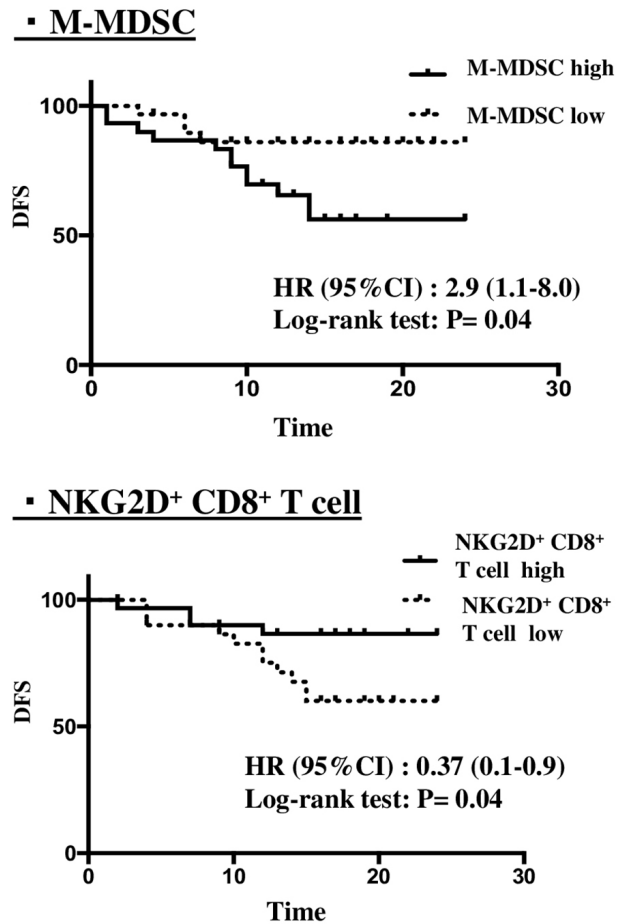

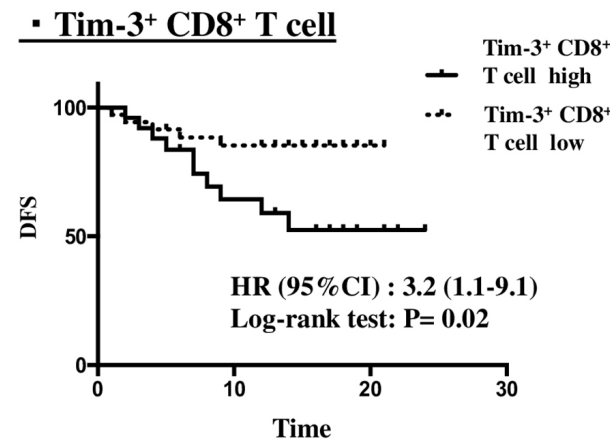

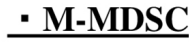

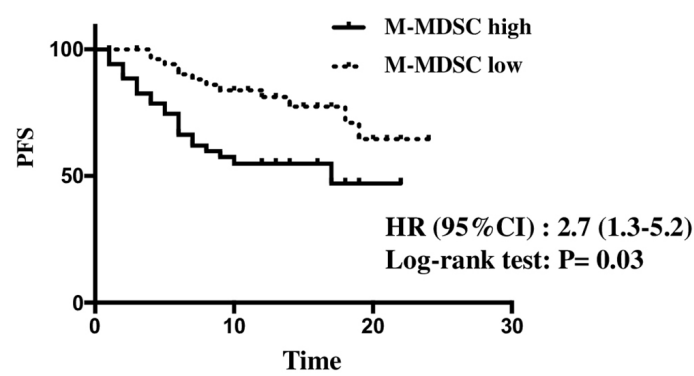

Figure 4. Association between the numbers of M-MDSCs, NKG2D ${ }^{+} \mathrm{CD} 8^{+} \mathrm{T}$ cells and Tim- $3^{+} \mathrm{CD} 8^{+} \mathrm{T}$ cells with PFS. PFS curves were calculated using the Kaplan-Meier method and compared with the log-rank test. The Kaplan-Meier curves for PFS are shown according to the pretreatment quantities of M-MDSCs, NKG2D ${ }^{+}$CD8 ${ }^{+} \mathrm{T}$ cells and Tim-3 ${ }^{+}$CD8 ${ }^{+} \mathrm{T}$ cells. M-MDSCs, monocytic- myeloid-derived suppressor cells; NKG2D, natural killer group 2 member A; Tim-3, T cell immunoglobulin and mucin domain-3, PFS, progression-free survival.
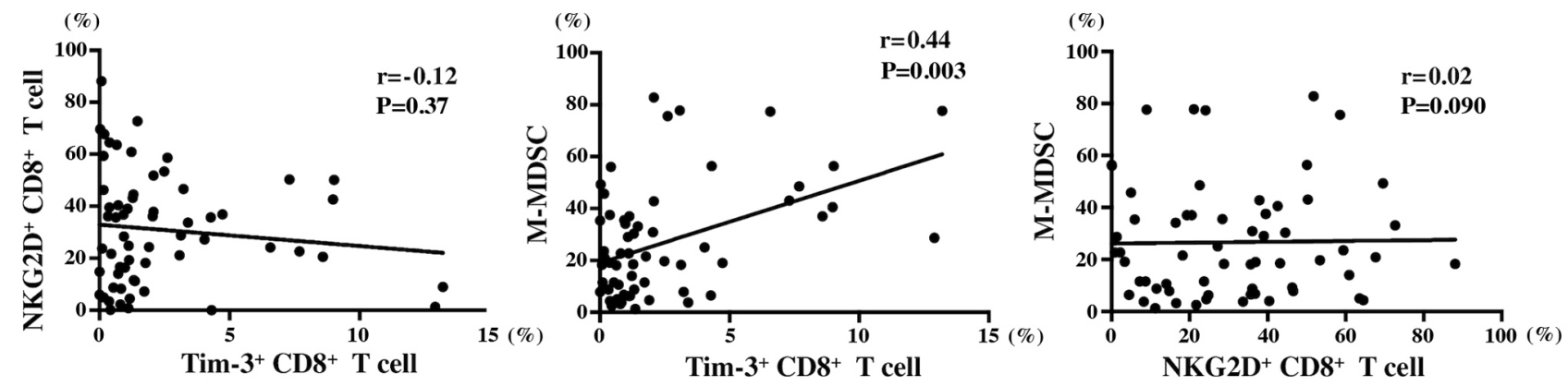

Figure 5. Correlations between the numbers of M-MDSCs, Tim- $3^{+} \mathrm{CD} 8^{+} \mathrm{T}$ cells and NKG2D ${ }^{+} \mathrm{CD} 8^{+} \mathrm{T}$ cells, with each other. Pearson's correlation coefficient is indicated as 'r' M-MDSCs, monocytic-myeloid-derived suppressor cells; Tim-3, T cell immunoglobulin and mucin domain-3; NKG2D, natural killer group 2 member A.

quantities of $\mathrm{Tim}-3^{+} \mathrm{CD} 8^{+} \mathrm{T}$ cells were associated with a lower DFS time (Table V).

Association between the number of M-MDSCs and PFS. The association between the number of immune subset cells and PFS time was examined. The patients with metastasis were divided into 'high' and 'low' groups. The cut-off/threshold value was used based on the median value of immune subset cells. The data indicated that the number of M-MDSCs was significantly associated with PFS time based on the Kaplan-Meier method and comparisons using the log-rank test (Fig. 4). A high number of M-MDSCs was significantly associated with poor PFS $(\mathrm{P}=0.03)$.

Pairwise correlation of Tim- $3^{+} C D 8^{+} T, M-M D S C$ and $N K G 2 D^{+} C D 8^{+} T$ cell number. The initial analysis demonstrated that the number of M-MDSCs, Tim- $3^{+} \mathrm{CD} 8^{+} \mathrm{T}$ cells and $\mathrm{NKG}_{2} \mathrm{D}^{+} \mathrm{CD}^{+} \mathrm{T}$ cells was associated with DFS time. Subsequently, Pearson's correlation analysis was performed between each pair of these variables, corresponding to the three different cell types (Fig. 5). No correlation was found between the number of Tim- $3^{+} \mathrm{CD} 8^{+} \mathrm{T}$ and $\mathrm{NKG} 2 \mathrm{D}^{+} \mathrm{CD} 8^{+}$ $\mathrm{T}$ cells $(\mathrm{r}=-0.12 ; \mathrm{P}=0.37)$. Similarly, no correlation was noted between the number of NKG2D ${ }^{+} \mathrm{CD}^{+} \mathrm{T}$ and M-MDSC cells $(\mathrm{r}=-0.02 ; \mathrm{P}=0.90)$. However, a weak correlation was observed between the number of M-MDSCs and Tim- $3^{+} \mathrm{CD} 8^{+} \mathrm{T}$ cells ( $\mathrm{r}=-0.44 ; \mathrm{P}=0.003$ ).

\section{Discussion}

In the present study, the immunological status of peripheral blood samples from patients with bone sarcoma and STS was investigated and also the association between the quantity of each immune cell subset and DFS/PFS times in patients with 
Table V. Multivariate analysis for disease-free survival.

\begin{tabular}{|c|c|c|}
\hline Clinicopathological characteristics & HR $(95 \% \mathrm{CI})$ & P-value \\
\hline \multicolumn{3}{|l|}{ M-MDSC, \% } \\
\hline$<21.4$ & Reference & \\
\hline$\geq 21.4$ & $2.3(0.6-8.3)$ & 0.17 \\
\hline \multicolumn{3}{|l|}{$\mathrm{NKG}^{2} \mathrm{D}^{+} \mathrm{CD}^{+} \mathrm{T}$ cell, $\%$} \\
\hline$<26.6$ & Reference & \\
\hline$\geq 26.6$ & $0.3(0.1-1.3)$ & 0.12 \\
\hline \multicolumn{3}{|l|}{$\mathrm{Tim}-3^{+} \mathrm{CD} 8^{+} \mathrm{T}$ cell, $\%$} \\
\hline$<8.7$ & Reference & \\
\hline$\geq 8.7$ & $3.7(1.0-12.9)$ & $0.04^{\mathrm{a}}$ \\
\hline
\end{tabular}

${ }^{\mathrm{a}} \mathrm{P}<0.05$. HR, hazard ratio; M-MDSC, monocytic myeloid-derived suppressor cells.

sarcoma. A higher number of M-MDSCs and Tim- $3^{+} \mathrm{CD}^{+}$ $\mathrm{T}$ cells was significantly associated with poor DFS times, while a higher number of $\mathrm{NKG} 2 \mathrm{D}^{+} \mathrm{CD}^{+} \mathrm{T}$ cells was significantly associated with longer DFS times. In addition, a higher number of M-MDSCs was significantly associated with poor PFS time and a weak positive correlation was found between the number of M-MDSCs and Tim- $3^{+} \mathrm{CD} 8^{+} \mathrm{T}$ cells.

In previous studies, high quantities of M-MDSCs in peripheral blood samples were identified as a poor prognostic factor for various types of cancer, such as melanoma, hepatocellular carcinoma, colorectal cancer and non-small cell lung cancer $(25,26,28,31,32)$. In patients with gastric cancer, a higher number of granulocyte-MDSCs was found to be a significant adverse factor for PFS time (33). The present study revealed that higher quantities of M-MDSCs were associated with poor DFS and PFS times. However, the granulocyte-MDSC ratio was not associated with DFS and PFS. The findings suggested similar results with those obtained in other types of tumors.

MDSCs are a heterogeneous population of granulocyte and monocyte-like cells that inhibit T cell function (23). Significant accumulation of MDSCs has been observed in patients with certain conditions, including chronic infections, transplantation and multiple malignancies compared with that in healthy subjects (23). The functions of MDSCs, including production of arginase 1 , release of reactive oxygen species and nitric oxide and secretion of immune-suppressive cytokines, leads to suppression of the immune responses (34). In addition, MDSCs are a potential therapeutic target. Clinical trials have examined the administration of multiple kinase inhibitors as inhibitors of MDSC proliferation $(35,36)$. In addition, phosphodiesterase-5 inhibitors have been used to deactivate MDSCs and all-trans retinoic acid has been used to prevent the differentiation of MDSCs (34). These trials are ongoing. The present study demonstrated that the number of M-MDSCs in patients with metastatic sarcoma was higher compared with that in patients with no high-grade sarcoma metastasis. The quantities of M-MDSCs may depend on the potential tumor clinical stage. Therefore, the number of M-MDSCs in patients with metastatic sarcoma may cause suppression of immune responses and consequently the inhibition of M-MDSC proliferation may be a potential therapeutic strategy.
As a co-inhibitory receptor present on the surface of T cells, Tim-3 plays a role in immune regulation (14). Galectin- 9 has been described as a binding receptor that mediates the T cell inhibitory effects of Tim-3 (37). Tim-3 has also been shown to be expressed on Th1 cells, as well as on $\mathrm{CD}^{+}$and $\mathrm{CD}^{+} \mathrm{T}$ cells, Treg, Th17, NK, DCs, monocytes and mast cells (38). Upregulation of TIM-3 expression has been observed on exhausted $\mathrm{CD}^{+} \mathrm{T}$ cells $(39,40)$. In certain tumors, such as lung cancer, lymphomas and breast cancer, higher quantities of $\mathrm{Tim}-3^{+} \mathrm{CD}^{+} \mathrm{T}$ cells were associated with poor disease outcomes (41-45). Ge et al (42) reported that $\mathrm{Tim}-3^{+} \mathrm{CD} 4^{+} \mathrm{T}$ and $\mathrm{CD} 8^{+} \mathrm{T}$ cells may serve as novel diagnostic and prognostic biomarkers of OS. However, to the best of our knowledge, the number of Tim $-3^{+} \mathrm{CD} 8^{+} \mathrm{T}$ cells in peripheral blood specimens from patients with STS has not been previously investigated, with respect to disease progression and patient survival. The present study indicated that the higher number of Tim- $3^{+} \mathrm{CD}^{+} \mathrm{T}$ cells was associated with poor DFS time in peripheral blood specimens derived from patients with bone sarcoma and STS.

The results of the present study suggested that the host immune response to tumors occurred in some, but not all, patients with bone sarcomas and STSs. Feng and Guo (46) demonstrated that the Tim-3 protein was overexpressed and that its mRNA expression levels were increased in OS tissues in vitro, as demonstrated by immunohistochemistry and reverse transcription-quantitative PCR. These findings suggested that the anti-Tim-3 antibody may exert significant tumor-associated effects on STS cells, as well as on T cells expressing the Tim-3 protein on their surface.

In addition, the present study indicated that high levels of $\mathrm{NKG}_{2} \mathrm{D}^{+} \mathrm{CD}^{+} \mathrm{T}$ cells were favorable factors for DFS time in patients with early stage bone sarcoma and STS. NKG2D is a stimulatory receptor expressed on the surface of NK cells and subsets of $\mathrm{T}$ cells (47). The function of NKG2D, as a co-stimulatory molecule on the surface of tumor infiltrating lymphocytes, involves its ligands, MICA/B and ULBPs, which are present in tumors, as well as the stimulation of the antitumor immunity $(48,49)$. Several studies have shown that the protein expression levels of NKG2D were associated with optimal outcomes in patients with cancer, such as nasopharyngeal carcinoma, cervical cancer and pancreatic cancer (50-52). Similarly, the findings from the present study suggested that high levels of NKG2D ${ }^{+} \mathrm{CD}^{+} \mathrm{T}$ cells were found to be favorable factors for DFS time in patients with early stage bone sarcoma and STS.

Furthermore, a high number of M-MDSCs was identified as a poor prognostic factor, indicating low PFS time in patients with metastasis. These observations suggested that immune surveillance, i.e. the host immune reaction against cancer, existed in patients with bone sarcomas and STSs. Notably, a high number of M-MDSCs was associated with DFS and PFS times, suggesting that it could be used as a prognostic factor.

In advanced cancer progression cases, the number of immunosuppressor cells, such as Tregs and MDSCs typically increases according to their tumor volume. Furthermore, $\mathrm{T}$ cell function is strongly suppressed. Therefore, the activation of the surface markers, such as Tim-3 and NKG2D and the associated fatigue caused on $\mathrm{T}$ cells may not correlate with prognosis in patients who are at the late disease stages (53-55). 
The present study contains certain limitations. The cohort was small, since bone sarcomas and STSs are rare tumors. Furthermore, it is important to identify associations between the immunological status of peripheral blood samples and the findings of pathological specimens, and to compare the immune status between patients with non-metastatic sarcoma and with patients with subsequent metastatic to predict prognosis. However, in the current study, specimens were not collected in the same patient at subsequent metastases. These aspects will be investigated in future studies. In addition, the interference of other factors, such as chemotherapy could not be excluded. Therefore, patients with high-grade sarcoma and no metastasis or those with metastatic sarcoma were only included to minimize the impact of differences in disease background and interventions. This is a preliminary, exploratory study and the results will be subsequently validated in a larger number of patients in the future.

In conclusion, the present study demonstrated that the immune status of patients with high-grade sarcoma and no metastasis or those with metastatic sarcoma who were treated with non-immunotherapy methods was associated with PFS or DFS times. These results may indicate that patients with bone sarcoma and STS, who develop an antitumor immune response over the natural course of their disease and those who develop a strong antitumor immune response, may have improved disease outcomes. The results of the present study may aid the development of novel strategies for sarcoma treatment based on the use of specific biomarkers or immunotherapeutic targets.

\section{Acknowledgements}

The authors would like to thank Mr. Masafumi Fuse, Ms Moeko Inoue and Dr Tetsuhiko Asao (all Department of Experimental Therapeutics and Exploratory Oncology Research and Clinical Trial Center, National Cancer Center Hospital, Tokyo, Japan) for their useful discussion with respect to the writing of the manuscript.

\section{Funding}

This study was supported by the Japan Society for the Promotion of science (JSPS), Grant-in Aid for Scientific Research (B) (grant no. 15H04964), JSPS, Grant-in Aid for Scientific Research (C) (grant no. 17K07208), JSPS, Grant-in Aid for Young Scientists B) (grant no. 16K20076), JSPS, Grant-in Aid for Young Scientists (grant no. 18K16634) and the Uehara Memorial Foundation and The Nakatomi Foundation.

\section{Availability of data and materials}

The datasets used and/or analyzed during the current study are available from the corresponding author on reasonable request.

\section{Authors' contributions}

EK, AK and SK supervised the research. YK, EK, YS, TN, KK and SK designed the study and performed the experiments.
YK, EK, DK, YT, ME, FN, AK obtained patient consent and collected the samples. YK and AI analyzed and interpreted the data. All authors wrote the manuscript and approved the final version for publication.

\section{Ethics approval and consent to participate}

This study was approved by the Institutional Review Board (approval no. 2014-287) from the National Cancer Center (Tokyo, Japan). All participants provided written informed consent.

\section{Patient consent for publication}

Not applicable.

\section{Competing interests}

Shigehisa Kitano reports personal fees from Astra Zeneca, Chugai Pharmaceutical Co., Ltd., Pfizer, Inc., Sanofi S.A., Nippon Kayaku Co., Ltd., Meiji Seika Kaisha, Ltd., Taiho Pharmaceutical Co., Ltd., Novartis International AG, Daiichi-Sankyo Co., Ltd., personal fees from Merck Sharp and Dohme Corp., Kyowa Kirin Co., Ltd., Celgene Corporation, Sumitomo Dainippon Pharma Co., Ltd., Astellas Pharma, Inc., Ono Pharmaceutical Co., Ltd., Bristol-Myers Squibb Company, AYUMI Pharmaceutical Corporation, Rakuten Medical, Inc., and Pharmaceuticals and Medical Devices Agency. In addition, grants and personal fees from Boehringer Ingelheim, Eisai Co., Ltd., and Regeneron Pharmaceuticals, Inc., and grants from Gilead Sciences, Inc., Japan Agency for Medical Research and Development, and Japan Society for the Promotion of Science, outside the submitted work.

\section{References}

1. Zambo I and Veselý K: WHO classification of tumours of soft tissue and bone 2013: The main changes compared to the 3rd edition. Cesk Patol 50: 64-70, 2014.

2. Gelderblom H, Blay JY, Seddon BM, Leahy M, Ray-Coquard R, Sleijfer S, Kerst JM, Rutkowski P, Bauer S, Ouali M, et al: Brostallicin versus doxorubicin as first-line chemotherapy in patients with advanced or metastatic soft tissue sarcoma: an European Organisation for Research and Treatment of Cancer Soft Tissue and Bone Sarcoma Group randomised phase II and pharmacogenetic study. Eur J Cancer 50: 388-396, 2014.

3. Mirabello L, Troisi RJ and Savage SA: International osteosarcoma incidence patterns in children and adolescents, middle ages and elderly persons. Int J Cancer 125: 229-234, 2009.

4. Esiashvili N, Goodman M and Marcus RB Jr: Changes in incidence and survival of Ewing sarcoma patients over the past 3 decades: Surveillance Epidemiology and End Results data. J Pediatr Hematol Oncol 30: 425-430, 2008.

5. Goorin AM, Schwartzentruber DJ, Devidas M, Gebhardt MC, Ayala AG, Harris MB, Helman LJ, Grier HE and Link MP; Pediatric Oncology Group: Presurgical chemotherapy compared with immediate surgery and adjuvant chemotherapy for nonmetastatic osteosarcoma: Pediatric Oncology Group Study POG-8651. J Clin Oncol 21: 1574-1580, 2003.

6. Nesbit ME Jr, Gehan EA, Burgert EO Jr, Vietti TJ, Cangir A, Tefft M, Evans R, Thomas P, Askin FB and Kissane JM: Multimodal therapy for the management of primary, nonmetastatic Ewing's sarcoma of bone: A long-term follow-up of the First Intergroup study. J Clin Oncol 8: 1664-1674, 1990.

7. Italiano A, Mir O, Cioffi A, Palmerini E, Piperno-Neumann S, Perrin C, Chaigneau L, Penel N, Duffaud F, Kurtz JE, et al: Advanced chondrosarcomas: Role of chemotherapy and survival. Ann Oncol 24: 2916-2922, 2013. 
8. George B, Bresson D, Herman P and Froelich S: Chordomas: A review. Neurosurg Clin N Am 26: 437-452, 2015.

9. Swann JB and Smyth MJ: Immune surveillance of tumors. J Clin Invest 117: 1137-1146, 2007.

10. Pardoll DM: The blockade of immune checkpoints in cancer immunotherapy. Nat Rev Cancer 12: 252-264, 2012.

11. McCoy KD and Le Gros G: The role of CTLA-4 in the regulation of T cell immune responses. Immunol Cell Biol 77: 1-10, 1999.

12. Nishimura $\mathrm{H}$ and Honjo T: PD-1: An inhibitory immunoreceptor involved in peripheral tolerance. Trends Immunol 22: 265-268, 2001.

13. He Y, Rivard CJ, Rozeboom L, Yu H, Ellison K, Kowalewski A, Zhou C and Hirsch FR: Lymphocyte-activation gene-3, an important immune checkpoint in cancer. Cancer Sci 107 1193-1197, 2016

14. Cheng L and Ruan Z: Tim-3 and Tim-4 as the potential targets for antitumor therapy. Hum Vaccin Immunother 11: 2458-2462, 2015.

15. Riha P and Rudd CE: CD28 co-signaling in the adaptive immune response. Self Nonself 1: 231-240, 2010.

16. Redmond WL, Ruby CE and Weinberg AD: The role of OX40-mediated co-stimulation in T-cell activation and survival Crit Rev Immunol 29: 187-201, 2009.

17. Palazón A, Teijeira A, Martínez-Forero I, Hervás-Stubbs S, Roncal C, Peñuelas I, Dubrot J, Morales-Kastresana A, Pérez-Gracia JL, Ochoa MC, et al: Agonist anti-CD137 mAb act on tumor endothelial cells to enhance recruitment of activated T lymphocytes. Cancer Res 71: 801-811, 2011.

18. Dong C, Juedes AE, Temann UA, Shresta S, Allison JP, Ruddle NH and Flavell RA: ICOS co-stimulatory receptor is essential for T-cell activation and function. Nature 409: 97-101, 2001.

19. Pende D, Cantoni C, Rivera P, Vitale M, Castriconi R, Marcenaro S, Nanni M, Biassoni R, Bottino C, Moretta A, et al: Role of NKG2D in tumor cell lysis mediated by human NK cells: Cooperation with natural cytotoxicity receptors and capability of recognizing tumors of nonepithelial origin. Eur J Immunol 31: 1076-1086, 2001

20. Overman MJ, McDermott R, Leach JL, Lonardi S, Lenz HJ Morse MA, Desai J, Hill A, Axelson M, Moss RA, et al: Nivolumab in patients with metastatic DNA mismatch repair-deficient or microsatellite instability-high colorectal cancer (CheckMate 142): An open-label, multicentre, phase 2 study. Lancet Oncol 18: 1182-1191, 2017.

21. Capdevila J, Wirth LJ, Ernst T, Ponce Aix S, Lin CC, Ramlau R, Butler MO, Delord JP, Gelderblom H, Ascierto PA, et al: PD-1 blockade in anaplastic thyroid carcinoma. J Clin Oncol 38 2620-2627, 2020.

22. Armand P, Lesokhin A, Borrello I, Timmerman J, Gutierrez M, Zhu L, Popa McKiver M and Ansell SM: A phase 1b study of dual PD-1 and CTLA-4 or KIR blockade in patients with relapsed/refractory lymphoid malignancies. Leukemia: Jun 29 , 2020 (Epub ahead of print). doi: 10.1038/s41375-020-0939-1.

23. Gabrilovich DI and Nagaraj S: Myeloid-derived suppressor cells as regulators of the immune system. Nat Rev Immunol 9 . $162-174,2009$

24. Kondělková K, Vokurková D, Krejsek J, Borská L, Fiala Z and Ctirad A: Regulatory T cells (TREG) and their roles in immune system with respect to immunopathological disorders. Acta Med (Hradec Kralove) 53: 73-77, 2010.

25. Tada K, Kitano S, Shoji H, Nishimura T, Shimada Y, Nagashima K, Aoki K, Hiraoka N, Honma Y, Iwasa S, et al: Pretreatment immune status correlates with progression-free survival in chemotherapy-treated metastatic colorectal cancer patients. Cancer Immunol Res 4: 592-599, 2016.

26. Kitano S, Postow MA,Ziegler CG, Kuk D, Panageas KS, Cortez C, Rasalan T, Adamow M, Yuan J, Wong P, et al: Computational algorithm-driven evaluation of monocytic myeloid-derived suppressor cell frequency for prediction of clinical outcomes. Cancer Immunol Res 2: 812-821, 2014.

27. Gonda K, Shibata M, Ohtake T, Matsumoto Y, Tachibana K, Abe N, Ohto H, Sakurai K and Takenoshita S: Myeloid-derived suppressor cells are increased and correlated with type 2 immune responses, malnutrition, inflammation, and poor prognosis in patients with breast cancer. Oncol Lett 14: 1766-1774, 2017.

28. Arihara F, Mizukoshi E, Kitahara M, Takata Y, Arai K, Yamashita T, Nakamoto $Y$ and Kaneko S: Increase in CD14 ${ }^{+}$HLA-DR ${ }^{-/ l o w}$ myeloid-derived suppressor cells in hepatocellular carcinoma patients and its impact on prognosis. Cancer Immunol Immunother 62: 1421-1430, 2013.
29. Kotsakis A, Harasymczuk M, Schilling B, Georgoulias V, Argiris A and Whiteside TL: Myeloid-derived suppressor cell measurements in fresh and cryopreserved blood samples. J Immunol Methods 381: 14-22, 2012

30. Eisenhauer EA, Therasse P, Bogaerts J, Schwartz LH, Sargent D, Ford R, Dancey J, Arbuck S, Gwyther S, Mooney M, et al: New response evaluation criteria in solid tumours: Revised RECIST guideline (version 1.1). Eur J Cancer 45: 228-247, 2009.

31. Gabitass RF, Annels NE, Stocken DD, Pandha HA and Middleton GW: Elevated myeloid-derived suppressor cells in pancreatic, esophageal and gastric cancer are an independent prognostic factor and are associated with significant elevation of the Th2 cytokine interleukin-13. Cancer Immunol Immunother 60 1419-1430, 2011.

32. Vetsika EK, Koinis F, Gioulbasani M, Aggouraki D, Koutoulaki A, Skalidaki E, Mavroudis D, Georgoulias V and Kotsakis A: A circulating subpopulation of monocytic myeloid-derived suppressor cells as an independent prognostic/ predictive factor in untreated non-small lung cancer patients. J Immunol Res 2014: 659294, 2014.

33. Shoji H, Tada K, Kitano S, Nishimura T, Shimada Y, Nagashima K, Aoki K, Hiraoka N, Honma Y, Iwasa S, et al: The peripheral immune status of granulocytic myeloid-derived suppressor cells correlates the survival in advanced gastric cancer patients receiving cisplatin-based chemotherapy. Oncotarget 8: 95083-95094, 2017.

34. Wesolowski R, Markowitz J and Carson WE III: Myeloid derived suppressor cells - a new therapeutic target in the treatment of cancer. J Immunother Cancer 1: 10, 2013.

35. Zhou J, Liu M, Sun H, Feng Y, Xu L, Chan AW, Tong JH, Wong J, Chong CC, Lai PB, et al: Hepatoma-intrinsic CCRK inhibition diminishes myeloid-derived suppressor cell immunosuppression and enhances immune-checkpoint blockade efficacy. Gut 67: 931-944, 2018.

36. Sade-Feldman M, Kanterman J, Klieger Y, Ish-Shalom E, Olga M, Saragovi A, Shtainberg H, Lotem M and Baniyash M: Clinical significance of circulating $\mathrm{CD}_{3}{ }^{+} \mathrm{CD} 11 \mathrm{~b}^{+} \mathrm{HLA}-\mathrm{DR}$ myeloid cells in patients with stage IV melanoma treated with Ipilimumab. Clin Cancer Res 22: 5661-5672, 2016.

37. Zhu C, Anderson AC, Schubart A, Xiong H, Imitola J, Khoury SJ, Zheng XX, Strom TB and Kuchroo VK: The Tim-3 ligand galectin-9 negatively regulates $\mathrm{T}$ helper type 1 immunity. Nat Immunol 6: 1245-1252, 2005.

38. Gorman JV and Colgan JD: Regulation of T cell responses by the receptor molecule Tim-3. Immunol Res 59: 56-65, 2014.

39. Yan J, Zhang Y, Zhang JP, Liang J, Li L and Zheng L: Tim-3 expression defines regulatory $\mathrm{T}$ cells in human tumors. PLoS One 8: e58006, 2013.

40. Arai Y, Saito H and Ikeguchi M: Upregulation of TIM-3 and PD-1 on $\mathrm{CD}^{+}$and $\mathrm{CD} 8^{+} \mathrm{T}$ cells associated with dysfunction of cell-mediated immunity after colorectal cancer operation. Yonago Acta Med 55: 1-9, 2012.

41. Anderson AC: Tim-3, a negative regulator of anti-tumor immunity. Curr Opin Immunol 24: 213-216, 2012.

42. Ge W, Li J, Fan W, Xu D and Sun S: Tim-3 as a diagnostic and prognostic biomarker of osteosarcoma. Tumour Biol: Jul 3, 2017 (Epub ahead of print). doi.org/10.1177/1010428317715643.

43. Zhuang X, Zhang X, Xia X, Zhang C, Liang X, Gao L, Zhang X and Ma C: Ectopic expression of TIM-3 in lung cancers: A potential independent prognostic factor for patients with NSCLC. Am J Clin Pathol 137: 978-985, 2012.

44. Dorfman DM, Hornick JL, Shahsafaei A and Freeman GJ: The phosphatidylserine receptors, $\mathrm{T}$ cell immunoglobulin mucin proteins 3 and 4, are markers of histiocytic sarcoma and other histiocytic and dendritic cell neoplasms. Hum Pathol 41: $1486-1494,2010$

45. Yang ZZ, Grote DM, Ziesmer SC, Niki T, Hirashima M, Novak AJ, Witzig TE and Ansell SM: IL-12 upregulates TIM-3 expression and induces $\mathrm{T}$ cell exhaustion in patients with follicular B cell non-Hodgkin lymphoma. J Clin Invest 122: 1271-1282, 2012

46. Feng ZM and Guo SM: Tim-3 facilitates osteosarcoma proliferation and metastasis through the NF- $\kappa$ B pathway and epithelial-mesenchymal transition. Genet Mol Res: Sep 2, 2016 (Epub ahead of print). doi: 10.4238/gmr.15037844.

47. Groh V, Wu J, Yee C and Spies T: Tumour-derived soluble MIC ligands impair expression of NKG2D and T-cell activation. Nature 419: 734-738, 2002.

48. Raulet DH, Gasser S, Gowen BG, Deng W and Jung $\mathrm{H}$ : Regulation of ligands for the NKG2D activating receptor. Annu Rev Immunol 31: 413-441, 2013. 
49. Zafirova B, Wensveen FM, Gulin M and Polić B: Regulation of immune cell function and differentiation by the NKG2D receptor. Cell Mol Life Sci 68: 3519-3529, 2011.

50. Xu Y, Zhou L, Zong J, Ye Y, Chen G, Chen Y, Liao X, Guo Q Qiu S, Lin S, et al: Decreased expression of the NKG2D ligand ULBP4 may be an indicator of poor prognosis in patients with nasopharyngeal carcinoma. Oncotarget 8: 42007-42019, 2017.

51. Cho H, Chung JY, Kim S, Braunschweig T, Kang TH, Kim J, Chung EJ, Hewitt SM and Kim JH: MICA/B and ULBP1 NKG2D ligands are independent predictors of good prognosis in cervical cancer. BMC Cancer 14: 957, 2014.

52. Chen J, Xu H and Zhu XX: Abnormal expression levels of sMICA and NKG2D are correlated with poor prognosis in pancreatic cancer. Ther Clin Risk Manag 12: 11-18, 2015.

53. Gabrilovich DI: Myeloid-derived suppressor cells. Cancer Immunol Res 5: 3-8, 2017.
54. Tcyganov E, Mastio J, Chen E and Gabrilovich DI: Plasticity of myeloid-derived suppressor cells in cancer. Curr Opin Immunol 51: 76-82, 2018.

55. Kumar V, Patel S, Tcyganov E and Gabrilovich DI: The nature of myeloid-derived suppressor cells in the tumor microenvironment. Trends Immunol 37: 208-220, 2016.

c) (i) $(\Theta$ This work is licensed under a Creative Commons Attribution-NonCommercial-NoDerivatives 4.0 International (CC BY-NC-ND 4.0) License. 